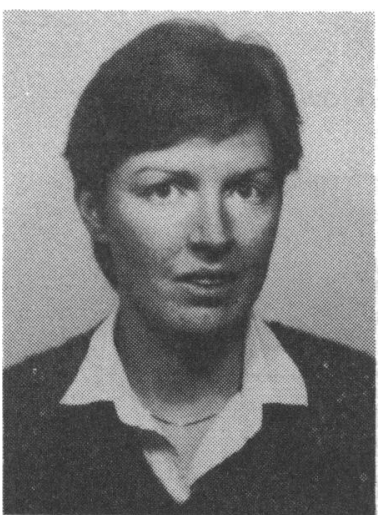

Catherine Horner

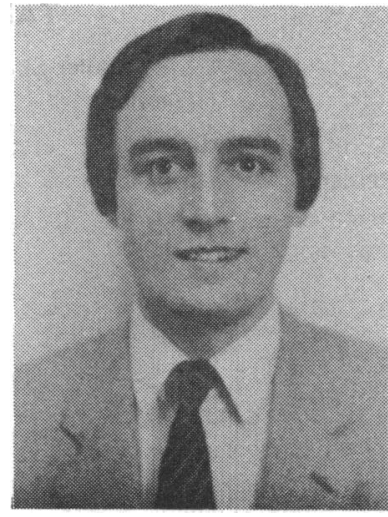

M. J. McCabe

\title{
ICE-SKATING AND ROLLER DISCO INJURIES IN DUBLIN
}

\author{
Catherine HORNER, MB, BCh, BAO, BA* and M. J. McCABE, MB, BCh, BAO, MA**
}

*Anatomy Department, Trinity College Dublin and * "Accident/Emergency Department, St. James's Hospital, Dublin 8

\section{ABSTRACT}

A comparative study was carried out on a series of 72 ice-skating and 57 roller skating injuries over a sixteen montte period. The average patient age was 20.5 years in the ice-skating group and 16.5 years in the roller skating group: Females predominated in both groups accounting for $72 \%$ of ice-skaters injured and $77 \%$ of roller skaters injured. Iceskaters sustained more serious injuries than roller skaters as was evident from the significant difference in fracture numbers in the two groups. Ice-skating fractures accounted for $40 \%$ of all injuries while roller skating fractures were only $14 \%$ of their total injuries. The majority of ice-skating fractures occurred in females. As a result of our study we recommend several preventative measures.

\section{INTRODUCTION}

During 1980 an ice-skating rink opened in south central Dublin. It joined several roller disco centres as new leisure outlets. The opening of these centres was associated with an increase in related injuries. As St. James's Hospital was the major accident and emergency centre in this area, it received a significant number of those injured. This study was designed to assess the nature of injuries sustained by those attending roller discos and ice rinks.

\section{METHODS}

From January 1981 to the end of April 1982 all first time attenders with ice-skating and roller disco injuries

\footnotetext{
* "Present address:

Central Middlesex Hospital

Acton Lane

London, NW10
}

were followed up for a period of twelve months. Patients were assessed and managed according to standard departmental protocols. Soft tissue injuries and minor fractures were treated in the accident department, more serious fractures being followed up in the orthopaedic outpatient clinic. Patients with major fractures and those sustaining loss of consciousness following head injuries were admitted for further treatment or observation as required.

\section{RESULTS}

A total of 129 persons attended, 57 from roller discos and 72 from the ice-skating rink. There was a significantly greater number of females in both groups. The average age was 16.5 in the roller disco group and 20.5 in the ice-skating (Table I).

Of the total 57 injuries in the roller skaters, there were $14 \%$ fractures, $16 \%$ head injuries with loss of consciousness and $70 \%$ soft tissue injuries including head injuries without loss of consciousness. However in the 
TABLE I

\begin{tabular}{lllll} 
& \multicolumn{2}{c}{ Roller Skaters } & \multicolumn{2}{c}{ Ice-Skaters } \\
& Female & Male & Female & Male \\
Number & 44 & 13 & 52 & 20 \\
Percentege & $77 \%$ & $23 \%$ & $72 \%$ & $28 \%$ \\
Mean age & $16 \pm 2$ & $17 \pm 3$ & $20 \pm 6$ & $21 \pm 8$ \\
Age range & $12-20$ & $13-26$ & $12-42$ & $13-41$
\end{tabular}

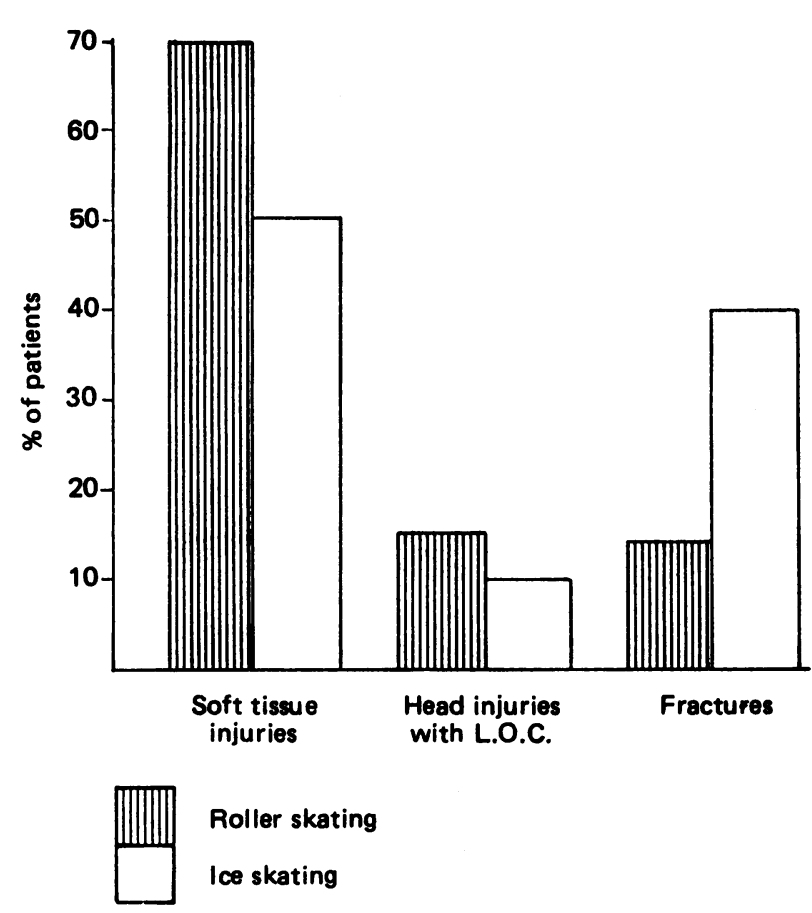

Fig. 1:

\section{Roller skating- \\ Comparison of upper and lower limb fractures}

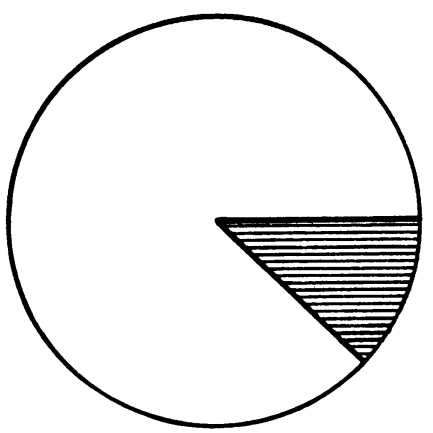

Upper limb fractures

(87.5\%)

Lower limb fractures

(12.5\%)

\section{lce-skating-}

Comparison of upper and lower limb fractures

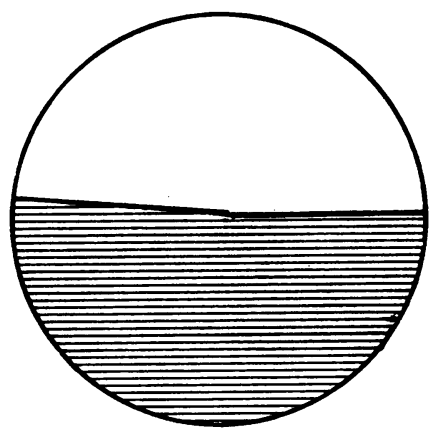

Upper limb fractures

(48.3\%)

Lower limb fractures

(51.7\%)

Fig. 3:

ice-skating group there were $40 \%$ fractures, $10 \%$ head injuries with loss of consciousness and $50 \%$ soft tissue injuries (Fig. 1). Fractures in the roller disco groups consisted of $87.5 \%$ upper limb and $12.5 \%$ lower limbo The ice-skating fractures differed significantly in that 48.3\% were upper limb and $52.7 \%$ were lower limb. The 8 roller skating fractures were 5 Colles, 1 Smith, 1 olecranon and 1 tarsal. The 29 fractures due to iceskating consisted of 7 Colles, 1 Smith, 1 olecranon, 1 clavicle, 1 humerus and 3 phalangeal in the upper limb and 3 tibio-fibular, 1 upper fibula, 8 lower fibula, 2 patellar and 1 lower tibia in the lower limb (Figs. 2 and 3). Females predominated in the ice-skating fracture group accounting for $\mathbf{2 3}$ of the 29 fractures.

In both groups the majority of patients were treated in the accident and emergency department and then discharged (72\% of roller skaters and $60 \%$ of ice-skaters). Those with more serious injuries were admitted and this accounted for $16 \%$ of roller skaters and $15 \%$ of iceskaters. The remaining $11 \%$ of roller skaters and $24 \%$ of ice-skaters were given immediate treatment and were further reviewed at the fracture clinic (Fig. 4). In each group one patient refused admission and these two are not included in the figure.

The attendance rate throughout the period illustrated in Fig. 5 shows an initial peak which fell and then levelled off at a fairly steady rate.

\section{DISCUSSION}

Injuries as a result of sporting accidents have assumed importance over the last five years. Spinal injuries as a

Fig. 2: 


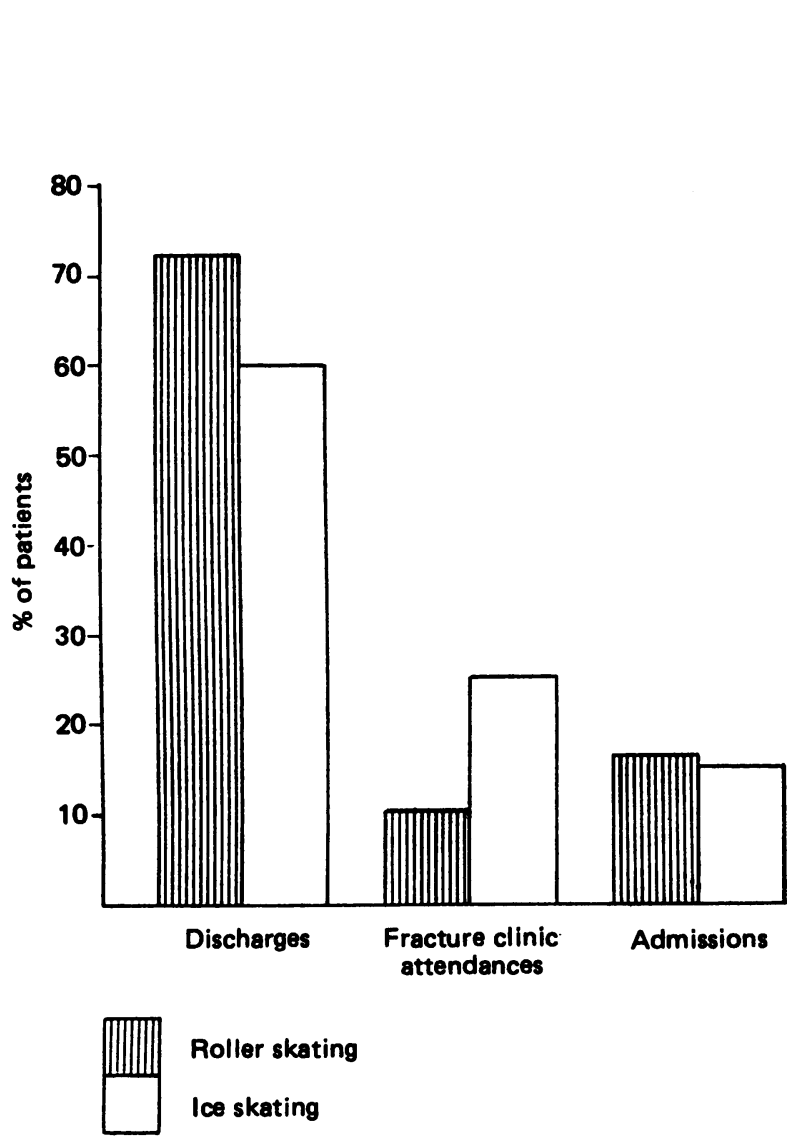

Fig. 4:

result of rugby and head injuries caused by boxing have been given most prominence. The results of these latter two may be catastrophic in the long term but lesser injuries due to minority interest activities should also be considered. Two examples of these types of sports are ice-skating and roller skating.
In this comparative study a definite difference was observed in the age profiles of the two groups. Roller skaters had an average age of 16.5 years which was comparable to that of Dowey (1982) but differed from that of Corcoran (1980), Ferkel et al (1981) and Kvidera and Frankel (1983). In the ice-skating group the mean age was 20.5 years which was greater than that found by Biener and Müller (1973) in their extensive study. The age difference noted between the two groups corresponds with the age groups attending the local rinks. The relative cost of admission probably explains this difference. Children were more likely to attend roller discos than adults.

The sex ratio was evenly distributed for participation in these sports, however there was a higher incidence of females injured. These results are in agreement with previous studies carried out by numerous authors on roller skaters (Bunker, 1983; Corcoran, 1980; Dowey, 1982, Ferkel et al, 1981; Kvidera and Frankel, 1983; Wilkinson *1982), but disagree with that of Biener and Müller (1973) who observed a predominance of males in ice-skating, but this study was carried out more than ten years before the others mentioned; fashions change!

Soft tissue injuries accounted for the majority in both groups (70\% of roller skaters and $50 \%$ of ice-skaters). However fractures contributed significantly in the iceskating group, accounting for $40 \%$ of injuries, while the roller skaters had only $14 \%$. Our ice-skating results are more comparable with those in a skateboarding survey by Christian and Khan (1980) than to our roller skating group. Twenty-three of the twenty-nine iceskating fractures occurred in females and perhaps the fact that girls are lighter and less strong physically may account for these results. However if this is the case we would expect a similar proportion of females with fractures in the roller skating group which did not occur

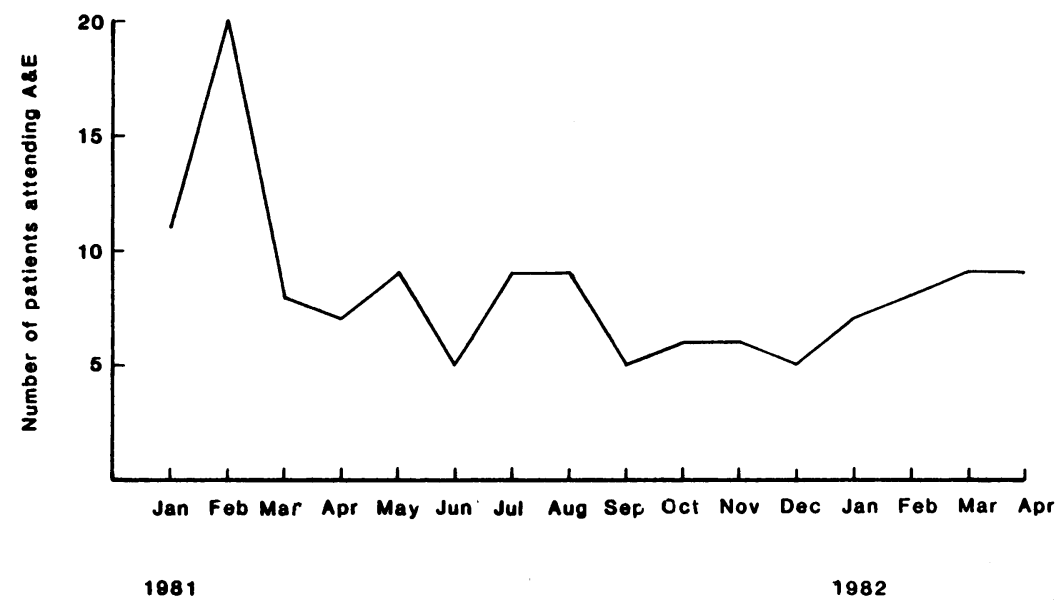

Fig. 5: 
In the roller skating group $87.5 \%$ of fractures involved the upper limb, particularly the wrist which agrees with studies carried out by Bunker (1983), Dowey (1982), Ferkel et al (1981), Kvidera and Frankel (1983), Ullis (1979) and Wilkinson (1982). Ice-skating fractures were fairly evenly distributed between upper and lower limbs (48\% upper limb and 52\% lower limb).

Roller skating is a faster sport but one has better control than in ice-skating. This may explain why roller skaters had more soft tissue injuries and less fractures. Also, the majority of upper limb fractures in roller skaters can be attributed to their using the upper limb as a defence mechanism in falls. Ice-skaters' lower limb fractures were mainly due to abduction-rotation movements of the ankle associated with rapid deceleration. Head injuries with loss of consciousness were of similar proportions in the two groups.

Attendance rates at the accident and emergency centre were higher just after several of the rinks opened and later became fairly constant. This suggests that skaters became more skilled or that the initial enthusiasm waned.

The majority of patients seen in casualty were discharged after treatment. This accounted for a large percentage of both groups. Similar numbers required admission in the two groups. The major difference observed between them was that more ice-skaters required follow-up at the fracture clinic due to their greater incidence of this injury type. Hence, overall they were the more costly in time and money to the health board.

Injuries from leisure time activities may lead not only to direct problems due to the injury itself but also to socioeconomic loss because of absence from work. We noted that the length of time off work (estimated from the social welfare certificates) was comparable with that expected from similar injuries due to industrial or traffic accidents. The ice-skating group had an overall longer absence from work. Recently the major Irish football association (Gaelic Athletic Association) has introduced a voluntary insurance scheme for all its members. This seeks to defray the losses incurred by players due to medical expenses and absence from work. A similar scheme might usefully be adopted for all participant sporting activities.

\section{RECOMMENDATIONS}

1. Supervision should be compulsory for all skaters especially children under fourteen years, to ensures good conduct at all times. Since our communication with the various rinks we can state that the present standard of supervision is quite good.

2. Instruction and guidance should be freely available to encourage improvement in standards.

3. It may be useful to segregate groups of skaters according to their skills and capabilities.

4. Protective clothing such as helmets, wrist bands and elbow and knee pads should be recommended to skaters.

5. Skating boots should be of a high standard with sufficient leg length to support the ankle since many of the fractures involved the lower tibia and fibula.

6. A voluntary insurance scheme should be available

7. All injuries in one city or area should be referred where possible to the same accident centre.

\section{ACKNOWLEDGEMENTS}

We are grateful to the casualty staff at St. James' Hospital for their assistance in recording cases and to Mr. F. Ward, Orthopaedic consultant for allowing us to report on his patients. Also we thank Ms. Siobhan Green for her help with the drawings.

\section{REFERENCES}

Biener, V. K. and Müller, P., 1973 “Eislaufunfälle-Epidemiologie und Prävention”. Fortschr.Med. 91 (5): 185-186.

Bunker, T. D. , 1983 "The 1982 epidemic - roller skating injuries". Brit.J.Sports Med. 17 (3): 205-208. 
Christian, M. S. and Khan, O., 1980 "Skateboard injuries - a current appraisal". Brit.J.Sports Med. 14 (2, 3): $102-104$.

Corcoran, M., 1980 "Survey of roller disco dance injuries". J.Irish Med.Assoc. 73 (6): 238-239.

Dowey, K. E., 1982 “A survey of roller discotheque injuries”. Brit.J.Sports Med. 16 (2): 85-88.

Ferkel, R. D., Mai, L. L., Ullis, K. C. and Finerman, G. A., 1981 "An analysis of roller skating injuries". Amer.J.Sports Med. 10 (1): 24-30.

Kvidera, D. J. and Frankel, V. H. 1983 "Trauma on eight wheels - a study of roller skating injuries in Seattle". Amer.J. Sports Med. 11 (1): 38-41.

Ullis, K., 1979 "Wrist injuries in roller skating". New Eng.J.Med. 301: 1350.

Wilkinson, A. J., 1982 “Injuries incurred at 'Roller Discos" ". Brit.Med.J. 284: 1163.

\section{F.I.M.S.}

\section{FEDERATION INTERNATIONALE DE MEDECINE SPORTIVE INTERNATIONAL FEDERATION OF SPORTS MEDICINE \\ Executive Committee President: E. Eriksson, MD (Sweden) \\ Secretary General: A. J. Ryan, MD (USA)}

EXECUTIVE COMMITTEE

\section{F.I.M.S. STATEMENT ON DOPING}

F.I.M.S. appeals for new initiatives in education and anti-doping propaganda aimed at protecting health by eliminating doping, including the inappropriate use of medicaments, by all sports people.

F.I.M.S., while recognising the continuing importance of doping control in the eradication of doping practices in sport, expresses concern that the increasing costs of control are being met at the expense of positive sports medical services in relation to the scientific preparation of athletes' health and fitness and facilities for the treatment of their medical and injury problems.

Contact: Dr. P. N. Sperryn, British Association of Sport and Medicine,

49 Blakes Lane,

New Malden,

Surrey KT3 6NS.

(01-949-0607)

SEPTEMBER 1983

\section{OBITUARY}

\section{Dr. Robert Edward Hamill, MB, BS, MRCS, LRCP, DObstRCOG}

Bob Hamill died on June 18th after a short illness, at the age of forty-eight. He qualified at St. Mary's Hospital, London, in 1961, and spent two years from 1965 in a South African mission hospital. He then entered general practice in Farnborough, Hampshire, and was Medical Officer to Farnborough Football Club, a post for which he was well suited as he had represented London University's Association Football Team, and later played for Farnborough. To extend his knowledge of sports medicine, he attended the 1979 BASM Sports Medicine course at Loughborough University, where he proved to be a very keen and interested member, well remembered and well liked by his fellow students and the staff. He joined BASM during the course, and kept up an active interest until the time of his death. We extend our deepest sympathy to his widow, his son and his two daughters. 